\title{
Migration and accumulation of heavy metals in disturbed landscapes in developing ore deposits, East Kazakhstan
}

\author{
Gulzhan BEISEYEVA ${ }^{1}$, Jilili ABUDUWAL2* ${ }^{2 *}$ \\ ${ }^{1}$ Kazakh Research Institute of Soil Science and Agrichemistry named for U.U.Uspanov, Almaty 050060, Kazakhstan; \\ ${ }^{2}$ State Key Laboratory of Desert and Oasis Ecology, Xinjiang Institute of Ecology and Geography, Chinese Academy of Sciences, \\ Urumqi 830011, China
}

\begin{abstract}
This paper studied the contents of heavy metals and their accumulation in the disturbed landscapes in ore deposits of East Kazakhstan. A total of 14 sites were examined in Zyrynovsky and Tishinsk deposits and Ridder town, and 50 soil samples were taken. Results indicated that the contents of heavy metals in the soil reached the maximum permissible concentration. Emissions of the zinc plant negatively affected the soil of nearby territories. In the remediated areas, a high concentration of heavy metals was observed at a depth where the bulk soil borders the rock. Accumulation of heavy metals on the surface of the remediated areas occurred due to biological accumulation in the plant. Plants transmitted heavy elements through the root system to the upper vegetative organs, making them accumulate in the upper layers of the soil. The heavy metals migrated and accumulated from the lower layers to the surface layers of the soil. The absence of soil meso-fauna resulted in the contamination of soil by heavy metals. The analysis of water samples, taken from the waste storages and the waste waters with heavy metals in the Zyryanovsk deposit and Ridder town, revealed severe water contamination.
\end{abstract}

Keywords: disturbed lands; dumps; waste storage; heavy metals; accumulation; migration; East Kazakhstan

Citation: Gulzhan BEISEYEVA, Jilili ABUDUWALI. 2013. Migration and accumulation of heavy metals in disturbed landscapes in developing ore deposits, East Kazakhstan. Journal of Arid Land, 5(2): 180-187.

Anthropogenic contamination to the natural environment causes a major concern on the negative consequences for human health. The landscapes and ecological situations of agricultural lands in the East Kazakhstan region (EKR) have been formed under the influence of natural and anthropogenic factors, most significant of which include the development of mining and industrial production. Increased extraction of fossils and increased processing of crude materials influence the process of intensive contamination of all landscape-forming components (air, ground surface, underground water, soil and vegetation) (Kasimov and Perelman, 1995).

Negative impact on the quality of lands in EKR was caused by contamination. In the region, the main sources of contamination to the soil surface are non-ferrous metal factories, mining complex, and the agricultural sector. The activities of 198 companies and organizations in EKR resulted in the deterioration of lands in an area of $12,800 \mathrm{hm}^{2}$, of which $6,268 \mathrm{hm}^{2}$ $(49 \%)$ were remediated. The soil surface of the region was contaminated by compounds of $\mathrm{Zn}, \mathrm{Cu}, \mathrm{Mn}, \mathrm{Cd}$, $\mathrm{Pb}$ and As.

Modern biogeochemical science raises the issue of the huge impact of human activities on the migration and redistribution of chemical elements in the biosphere. Studies on the biogeochemical processes of the source, distribution, migration and accumulation of heavy metals in the soil-plant-water and biota systems revealed theoretical issues in the interconnected systems of the biosphere (Min et al., 2010; Deepak and Keshav, 2012). Thus, these

*Corresponding author: Jilili ABUDUWALI (E-mail: jilil@ms.xjb.ac.cn) Received 2012-05-29; revised 2012-09-21; accepted 2012-12-25

(C) Xinjiang Institute of Ecology and Geography, Chinese Academy of Sciences, Science Press and Springer-Verlag Berlin Heidelberg 2013 
processes in technologically disturbed landscapes and under conditions of bioremediation of industrial dumps are different from the those taking place in the zonal undisturbed landscapes, where the contents of $\mathrm{Cu}, \mathrm{Pb}, \mathrm{Zn}, \mathrm{Cd}$ and other elements in soils are in higher concentrations compared with the soils in non-ore mining regions. The area of our study is a geochemical zone of ore anomalies.

The aims of our work are to study the biogeochemical processes of the migration and accumulation of heavy metals in the soil-plant-water system, and to evaluate the soil and environmental conditions of technologically-disturbed landscapes.

\section{Study area and methods}

The study was conducted in the technologically disturbed lands of Zyryanovsk and Tishinsk deposits and the areas adjacent to the zinc and lead plants in Ridder town of East Kazakhstan region. At the entrance to Zyryanovsk, we can see cone-shaped, extended, irregular embankments. They form the industrial dumps which present an aesthetically unattractive landscape. The relief, which can be referred to mature forms, has developed under anthropogenic accumulation. The disturbed lands, covering more than $200 \mathrm{hm}^{2}$ of Zyryanovsk quarry, have been formed as a result of mining activities. The dumps consist of mixed psephitic, gravel-pebble, sand, clay, and silt rocks. The territories, occupied by the tailing dumps, are technogenically disturbed lands. The tailing dumps are a source of environmental pollution. The total area of the old dump is $98 \mathrm{hm}^{2}$. Tailings from the concentration mill were discharged with the help of pipes. The discharge of wastes into the tailing dump stopped at the beginning of the 1970s, and now the marginal parts of the tailing dumps are overgrown with wood-shrub species. The discharge of tailings is being directed into a new tailing dump and it continues to extend. The new tailing dump is $6-8$ times larger than the old one.

Determination of heavy metals and other chemical elements in the soils, soil grounds, plants, water, and bottom sediments were carried out by using nuclearphysics and atomic-absorption methods. When taking soil samples for the test of micro- and mesofauna of the soil, the standard method was used (Gilyarov, 1975; Gilyarov and Striganova, 1987). For microarthropod analysis, soil samples were taken in a volume of $5 \mathrm{~cm} \times 5 \mathrm{~cm} \times 5 \mathrm{~cm}$, and for mesofauna study, taken from a size of $25 \mathrm{~cm} \times 25 \mathrm{~cm}$.

Extraction of microarthropods was conducted in Berleze-Tullgren thermoeklector (Bulanov-Zakhvatkin, 1952). From each site, soil samples were taken in the layers of $0-14 \mathrm{~cm}$ with $5-\mathrm{cm}$ intervals. In total, 14 sites were examined, with 50 samples being taken for microarthropod analysis and 61 for mesofauna study. These samples were then fixed in $70 \%$ alcohol. Subsequently, identification of the representatives of microarthropods and mesofauna was conducted according to the determinants of the faunas in the USSR. Generic taxonomic groups have been identified. Indicators of the number of specific components were given per $1 \mathrm{~m}^{2}$.

Evaluation of chemical contamination level of soils was conducted on the basis of indicators developed in joint geochemical studies of urban environment. Coefficient of chemical element concentration $(\mathrm{Kc})$ is defined as the ratio of its actual content $(\mathrm{C})$ in soil to the maximum permissible concentration (Cø). Total indicator of soil contamination is equal to the sum of coefficients of chemical element concentrations and is expressed in the following formula:

$$
K c=\frac{C}{C \varnothing} .
$$

The value of background concentrations of heavy metals is used to evaluate soil contamination with complex of metals on total index of pollution $Z c$ :

$$
Z c=\sum_{i=1}^{n} K c \text {. }
$$

Where, $Z c$ is total pollution index; $n$, quantity of defined ingredients; $K c$, coefficient of metal concentration which is equal to the ratio of the content of $i$, the metal in contaminated soil to the background.

Coefficient of chemical element migration in water means the ratio of chemical elements in the mineral balance of water to its content in the water-bearing rocks or Clarke element content in the lithosphere:

$$
K x=m x \cdot 100 / a \cdot n x \text {. }
$$


Where, $m x$, the content of the element $x$ in the water, $\mathrm{g} / \mathrm{L} ; a$, salinity of water, $\mathrm{g} / \mathrm{L} ; n x$, percent (by weight) of $x$ in the water-bearing rocks or in the lithosphere. The use of $K x$ allows us to compare the intensity of migration and concentration of common and rare items.

\section{Results and discussion}

\subsection{Contamination to soil}

Zonal soils for the study are various leached black soils in Zyryanovsk. The imperfect technology of mining, processing, purifying devices in enrichment plants and factories results in the contamination of all ecosystems in the biosphere of the study region. Heavy metals in the soil-plant-water systems in the technologically disturbed landscapes showed a specific regularity in the course of their migration and accumulation.

The total area of dumps in Zyryanovsk field is over $200 \mathrm{hm}^{2}$ (Figs. 1, 2). Dumps of the deposits contain high concentrations of heavy metals. The contents of $\mathrm{Zn}$ and $\mathrm{Pb}$ exceed the maximum permissible concentration (MPC) by $2 \%-45 \%$ and $3 \%-406 \%$, respectively. Such high concentrations of heavy metals in the dump rocks show a chaotic mixing of over-ore and ore containing rocks in the development of the deposit.

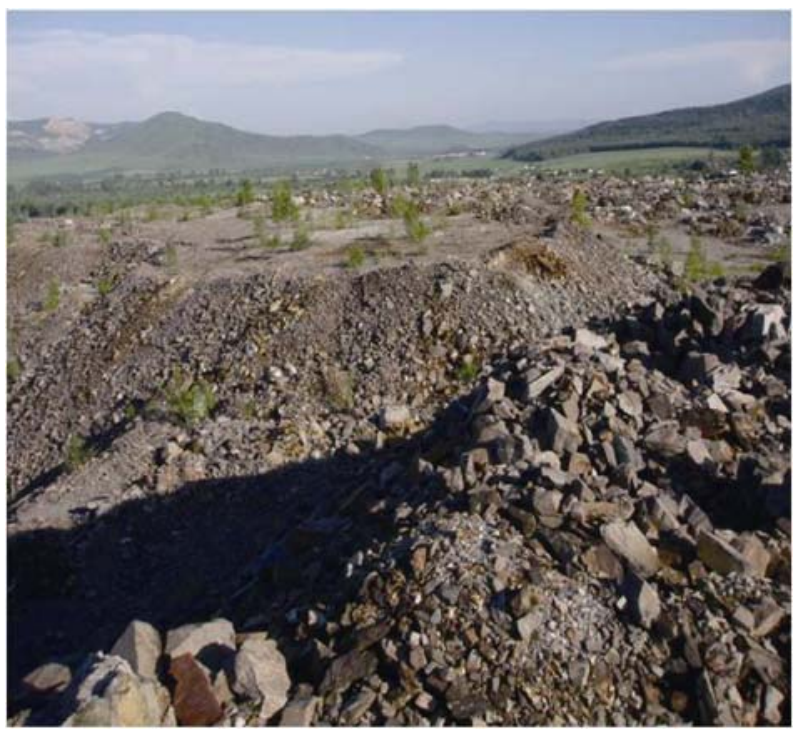

Fig. 1 Industrial dumps, with heights of 2-50 m, consist of psephitic rocks mixed with silt and clay. The volume of the dumps comes up to more than $10 \times 10^{8} \mathrm{~m}^{3}$.

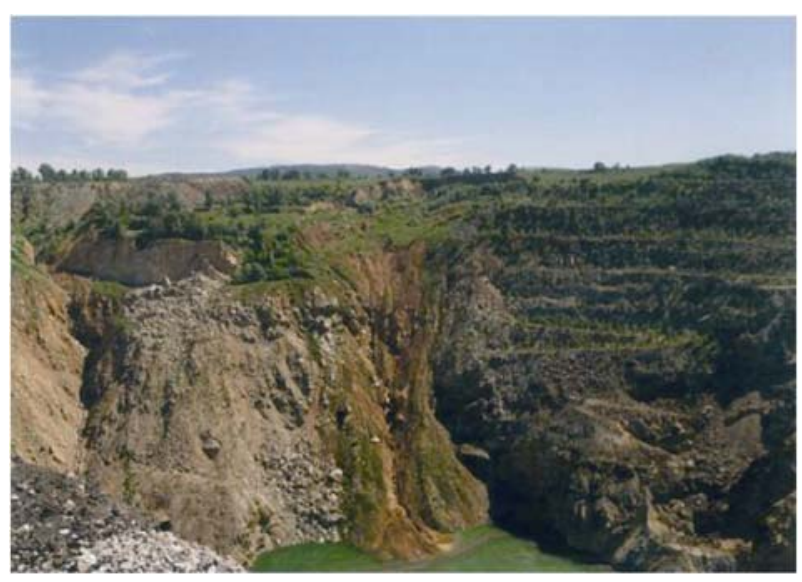

Fig. 2 A quarry is usually 220-250 m deep, with waste heaps of $50 \mathrm{~m}$ high and former mine gaps of 20-100 m wide. Tailing dumps consist of concentrated mill wastes (tailings).

The formation processes of soils were researched in experimental conditions: under natural overgrowing of tailing dumps. Hydro dumps (slurry, Fig. 3) in Zyryanovsk deposit are composed of tertiary red-colored clay. In the profile section (Fig. 4), located in the hydro dump in the upper $0-5 \mathrm{~cm}$ soil layer, the accumulation of heavy metals was observed. The order of element absorption is: $\mathrm{Zn}>\mathrm{Cr}>\mathrm{Pb}>\mathrm{Cu}$.

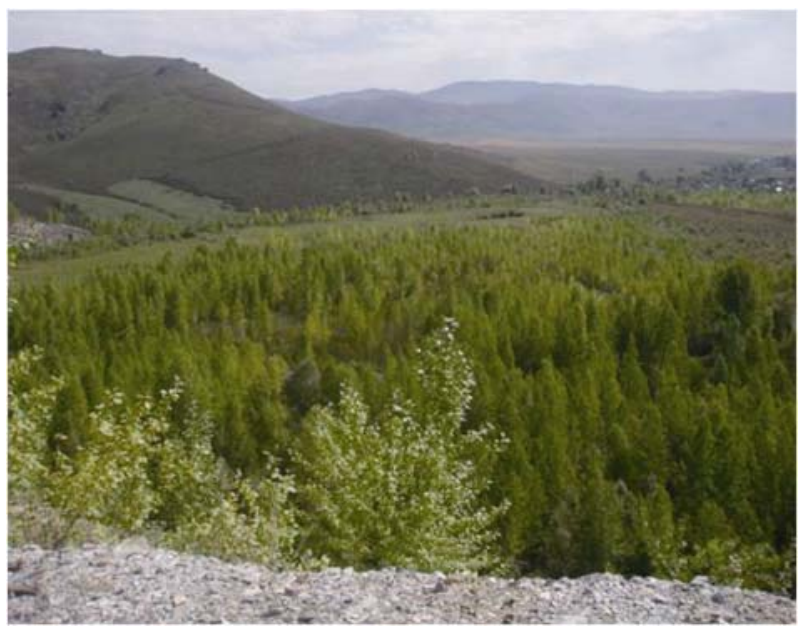

Fig. 3 Overgrown hydro dumps at the feet of industrial dumps

Technologically disturbed lands include the areas occupied by waste storages. The waste storage in Zyryanovsk mining plant covers an area of about 490 $\mathrm{hm}^{2}$, including $80 \mathrm{hm}^{2}$ of dusty surface (Fig. 5 , Table 1). Every year in the storage, about $1,308,133.17$ tons of dump wastes were stored (Mambetkaziev et al., 2001). It is known that at a wind speed of $5-6 \mathrm{~m} / \mathrm{s}$, 


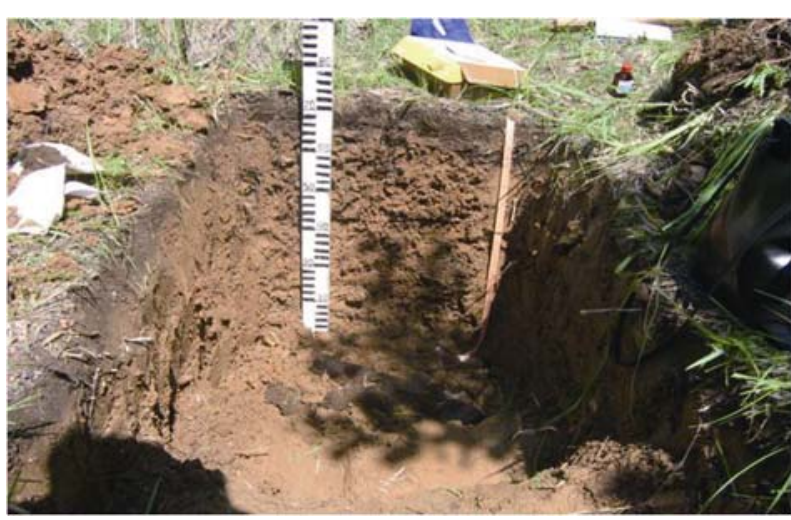

Fig. 4 Pit established in an overgrown hydro dump local wind erosion occurs, and at $18-20 \mathrm{~m} / \mathrm{s}$, dust storms occur in the air, in which a large number of eroded particles is drifted. The old waste storage of Zyryanovsk mining plant is one of the sources of pollution. In the samples taken from the waste storage,
$\mathrm{Zn}$ content exceeded the MPC by $68 \%-386 \%$, $\mathrm{Pb}$ by $8 \%-320 \%$, and $\mathrm{Cu}$ by $36 \%-200 \%$.

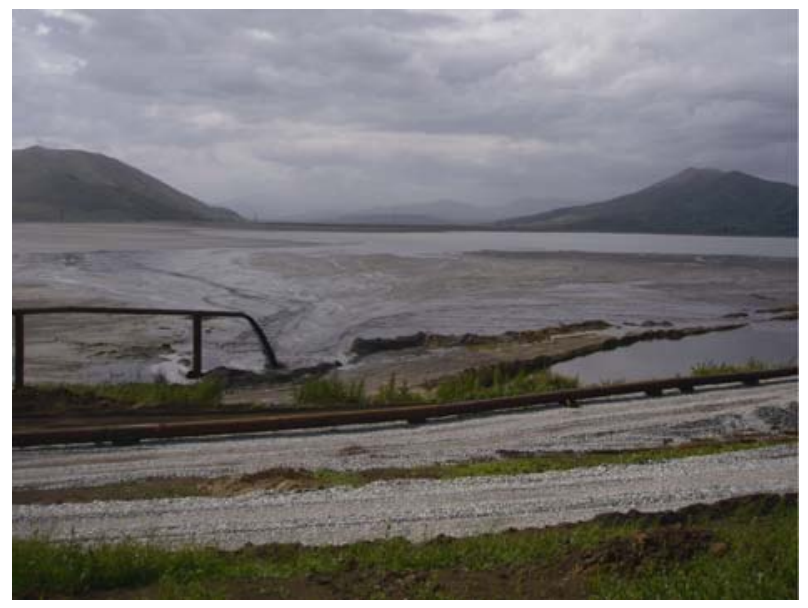

Fig. 5 Tailings getting into the tailing dump

Table 1 Contents of heavy metals in technogenically disturbed landscapes of Zyryanovsk deposit

\begin{tabular}{|c|c|c|c|c|c|c|c|c|c|}
\hline & $\begin{array}{c}\text { Depth of } \\
\text { sampling } \\
(\mathrm{cm})\end{array}$ & $\begin{array}{c}\mathrm{Cr} \\
(\mathrm{mg} / \mathrm{kg})\end{array}$ & $\begin{array}{c}\text { Exceeding of MPC } \\
\text { level (\%) }\end{array}$ & $\begin{array}{c}\mathrm{Pb} \\
(\mathrm{mg} / \mathrm{kg})\end{array}$ & $\begin{array}{c}\text { Exceeding } \\
\text { of MPC } \\
\text { level }(\%) \\
\end{array}$ & $\begin{array}{c}\mathrm{Zn} \\
(\mathrm{mg} / \mathrm{kg})\end{array}$ & $\begin{array}{c}\text { Exceeding of } \\
\text { MPC level } \\
(\%)\end{array}$ & $\begin{array}{c}\mathrm{Cu} \\
(\mathrm{mg} / \mathrm{kg})\end{array}$ & $\begin{array}{c}\text { Exceeding } \\
\text { of MPC } \\
\text { level }(\%) \\
\end{array}$ \\
\hline \multirow{4}{*}{$\begin{array}{c}\text { Hydro } \\
\text { dump, } \\
\text { section } 1\end{array}$} & $0-5$ & $80 \pm 9$ & 5.3 & $119 \pm 8$ & 19.8 & $796 \pm 48$ & 34.6 & $71 \pm 6$ & 23.8 \\
\hline & $5-11$ & $178 \pm 16$ & 11.9 & $41 \pm 5$ & 6.8 & $160 \pm 12$ & 7.0 & $76 \pm 7$ & 25.3 \\
\hline & $11-30$ & $161 \pm 16$ & 10.73 & $38 \pm 5$ & 6.3 & $139 \pm 11$ & 6.0 & $76 \pm 7$ & 25.3 \\
\hline & $30-35$ & $153 \pm 15$ & 10.7 & $33 \pm 5$ & 5.5 & $135 \pm 10$ & 5.86 & $71 \pm 7$ & 23.7 \\
\hline \multirow{5}{*}{$\begin{array}{c}\text { Zone of } \\
\text { leached } \\
\text { black soil, } \\
\text { section } 2\end{array}$} & $0-10$ & $155 \pm 15$ & 10.3 & $43 \pm 5$ & 7.2 & $153 \pm 11$ & 6.65 & $71 \pm 7$ & 23.8 \\
\hline & $10-37$ & $155 \pm 15$ & 10.3 & $29 \pm 4$ & 4.8 & $119 \pm 9$ & 5.17 & $66 \pm 6$ & 22.0 \\
\hline & $37-64$ & $169 \pm 14$ & 11.2 & $24 \pm 4$ & 4.0 & $129 \pm 9$ & 5.6 & $70 \pm 6$ & 23.3 \\
\hline & $64-95$ & $170 \pm 14$ & 11.3 & $28 \pm 4$ & 4.7 & $119 \pm 9$ & 5.17 & $70 \pm 6$ & 23.3 \\
\hline & $95-130$ & $141 \pm 15$ & 9.4 & $23 \pm 5$ & 3.8 & $103 \pm 9$ & 4.47 & $58 \pm 7$ & 19.3 \\
\hline \multirow{7}{*}{$\begin{array}{c}\text { Tailing } \\
\text { storage, } \\
\text { section } 3\end{array}$} & $0-10$ & $123 \pm 15$ & 8.2 & $1,693 \pm 102$ & 282 & $5,505 \pm 331$ & 239.3 & $443 \pm 28$ & 147.7 \\
\hline & $10-23$ & $79 \pm 13$ & 5.2 & $1,027 \pm 62$ & 171 & $5,152 \pm 310$ & 224.0 & $3,2521 \pm 21$ & 108.3 \\
\hline & $26-45$ & $135 \pm 16$ & 9.0 & $1,734 \pm 105$ & 289 & $8,885 \pm 534$ & 386.3 & $603 \pm 38$ & 201.0 \\
\hline & $45-60$ & $107 \pm 15$ & 7.1 & $1,453 \pm 88$ & 242 & $7,593 \pm 457$ & 330.1 & $442 \pm 28$ & 147.3 \\
\hline & $60-76$ & $105 \pm 14$ & 7.0 & $1,419 \pm 86$ & 236.5 & $5,929 \pm 357$ & 257.8 & $438 \pm 24$ & 146.0 \\
\hline & $76-87$ & $113 \pm 14$ & 7.5 & $1,919 \pm 115$ & 319.8 & $2,429 \pm 147$ & 105.6 & $361 \pm 24$ & 120.3 \\
\hline & $87-105$ & $170 \pm 15$ & 11.3 & $49 \pm 5$ & 8.2 & $1,569 \pm 85$ & 68.2 & $109 \pm 8$ & 36.3 \\
\hline
\end{tabular}

In the soil samples taken from the sections of the profiles in the lower horizons in the waste storage located near the zinc and lead plants in Ridder town, the decrease of heavy metals was observed (Table 2). According to statistics data, the variation coefficient for zinc is $4.3 \%-44.3 \%$, for copper $13.3 \%-53.4 \%$, and for lead $12 \%-82.2 \%$. In the soil samples collected near the waste storage, the highest coefficient of variation $(82.2 \%)$ in lead was observed. In the soil samples taken near the lead plant, the content of zinc exceeded the Clarke values of the element in the soil and in the lithosphere by $2.9 \%$ and $1.7 \%$, respectively, and was $2.07 \%$ lower than the MPC according to Kloke (1980).

The copper content was $2.4 \%$ higher than the Clarke values of the element in the soil and $2.09 \%$ lower than the MPC according to Kloke (1980). The lead content was higher than the Clarke values of the 
Table 2 Concentrations of heavy metals in the disturbed landscapes in the ore deposits of Ridder town

\begin{tabular}{|c|c|c|c|c|c|c|c|c|c|}
\hline & $\begin{array}{c}\text { Depth of } \\
\text { sampling }(\mathrm{cm})\end{array}$ & $\begin{array}{c}\mathrm{Cr} \\
(\mathrm{mg} / \mathrm{kg})\end{array}$ & $\begin{array}{l}\text { Exceeding of } \\
\text { MPC level (\%) }\end{array}$ & $\begin{array}{c}\mathrm{Cu} \\
(\mathrm{mg} / \mathrm{kg})\end{array}$ & $\begin{array}{l}\text { Exceeding of } \\
\text { MPC level }\end{array}$ & $\begin{array}{c}\mathrm{Zn} \\
(\mathrm{mg} / \mathrm{kg})\end{array}$ & $\begin{array}{c}\text { Exceeding of } \\
\text { MPC level (\%) }\end{array}$ & $\begin{array}{c}\mathrm{Pb} \\
(\mathrm{mg} / \mathrm{kg})\end{array}$ & $\begin{array}{l}\text { Exceeding of } \\
\text { MPC level (\%) }\end{array}$ \\
\hline \multirow{4}{*}{$\begin{array}{l}\text { Zinc plant, } \\
\text { section } 1\end{array}$} & $0-20$ & $173 \pm 17$ & 11.5 & $183 \pm 13$ & 30.5 & $6,713 \pm 404$ & 291.9 & $421 \pm 26$ & 70.2 \\
\hline & $20-58$ & $159 \pm 15$ & 10.6 & $83 \pm 7$ & 27.7 & $1,301 \pm 79$ & 56.6 & $184 \pm 12$ & 14 \\
\hline & $58-93$ & $152 \pm 15$ & 10.1 & $64 \pm 6$ & 21.3 & $129 \pm 10$ & 5.6 & $29 \pm 4$ & 4.8 \\
\hline & $93-115$ & $165 \pm 16$ & 11 & $70 \pm 7$ & 23.3 & $127 \pm 10$ & 5.5 & $25 \pm 4$ & 4.2 \\
\hline \multirow{5}{*}{$\begin{array}{l}\text { Zinc plant, } \\
\text { section } 2\end{array}$} & $0-25$ & $169 \pm 16$ & 11.3 & $203 \pm 14$ & 67.7 & $5,911 \pm 356$ & 257 & $404 \pm 25$ & 67.3 \\
\hline & $25-56$ & $158 \pm 15$ & 10.5 & $70 \pm 7$ & 23.3 & $313 \pm 20$ & 13.6 & $35 \pm 5$ & 5.8 \\
\hline & $56-81$ & $164 \pm 15$ & 10.9 & $66 \pm 6$ & 22 & $126 \pm 10$ & 5.47 & $30 \pm 4$ & 5 \\
\hline & $81-96$ & $176 \pm 16$ & 11.7 & $71 \pm 7$ & 23.7 & $126 \pm 10$ & 5.4 & $28 \pm 4$ & 4.7 \\
\hline & $96-115$ & $168 \pm 16$ & 11.2 & $71 \pm 7$ & 23.7 & $129 \pm 10$ & 5.6 & $25 \pm 5$ & 4.2 \\
\hline \multirow{4}{*}{$\begin{array}{c}\text { Waste } \\
\text { storage, } \\
\text { section } 3\end{array}$} & $0-26$ & $151 \pm 15$ & 10.1 & $129 \pm 10$ & 43 & $972 \pm 60$ & 42.2 & $1,282 \pm 78$ & 213 \\
\hline & $26-56$ & $142 \pm 14$ & 9.5 & $60 \pm 6$ & 20 & $115 \pm 9$ & 5 & $26 \pm 4$ & 4.3 \\
\hline & $56-95$ & $153 \pm 14$ & 10.2 & $65 \pm 6$ & 21.7 & $115 \pm 9$ & 5 & $27 \pm 4$ & 4.5 \\
\hline & $95-117$ & $148 \pm 15$ & 9.9 & $62 \pm 7$ & 20.7 & $124 \pm 10$ & 5.3 & $24 \pm 5$ & 4 \\
\hline
\end{tabular}

element in the soil and in the lithosphere by $29.1 \%$ and $18.4 \%$, respectively, and exceeded the MPC of Kloke (1980) by $9.2 \%$ (Table 2).

In the study, the main heavy metals were identified, and they sourced the intake in the soil-plant-water system. The main contaminants were lead, zinc and copper, which originated from the lead plant $(\mathrm{Pb}, \mathrm{Zn})$, the zinc plant $(\mathrm{Zn}, \mathrm{Pb}, \mathrm{Cu})$, the tailing storage $(\mathrm{Pb}$, $\mathrm{Zn}, \mathrm{Cu}$ ) in Ridder town, and then the Zyryanovsk deposit (Table 3).

Table 3 Main contamination elements in the disturbed lands and their contamination sources

\begin{tabular}{|c|c|c|c|c|c|}
\hline Location & $\begin{array}{l}\text { Polluting } \\
\text { plants }\end{array}$ & Elements & MPC & $\begin{array}{l}\text { Exceeding } \\
\text { MPC (\%) }\end{array}$ & $\begin{array}{c}\text { Main } \\
\text { pollution } \\
\text { elements }\end{array}$ \\
\hline \multirow{3}{*}{$\begin{array}{c}\text { Near waste } \\
\text { storage }\end{array}$} & \multirow{3}{*}{$\begin{array}{l}\text { Lead plant in } \\
\text { Ridder }\end{array}$} & $\mathrm{Zn}$ & 23 & 19.3 & \multirow{3}{*}{$\mathrm{Pb}, \mathrm{Cu}, \mathrm{Zn}$} \\
\hline & & $\mathrm{Pb}$ & 6 & 367.5 & \\
\hline & & $\mathrm{Cu}$ & 3 & 99.8 & \\
\hline \multirow{3}{*}{$\begin{array}{l}200 \mathrm{~m} \text { from } \\
\text { zinc plant }\end{array}$} & \multirow{3}{*}{$\begin{array}{l}\text { Zinc plant in } \\
\text { Ridder }\end{array}$} & $\mathrm{Zn}$ & 23 & 22.1 & \multirow{3}{*}{$\mathrm{Pb}, \mathrm{Cu}, \mathrm{Zn}$} \\
\hline & & $\mathrm{Pb}$ & 6 & 201.5 & \\
\hline & & $\mathrm{Cu}$ & 3 & 157.1 & \\
\hline \multirow{3}{*}{$\begin{array}{l}500 \mathrm{~m} \text { from } \\
\text { zinc plant }\end{array}$} & \multirow{3}{*}{$\begin{array}{c}\text { Zinc plant in } \\
\text { Ridder }\end{array}$} & $\mathrm{Zn}$ & 23 & 20.5 & \multirow{3}{*}{$\mathrm{Pb}, \mathrm{Cu}, \mathrm{Zn}$} \\
\hline & & $\mathrm{Pb}$ & 6 & 121.8 & \\
\hline & & $\mathrm{Cu}$ & 3 & 79.7 & \\
\hline \multirow{3}{*}{$\begin{array}{c}\text { Near lead } \\
\text { plant }\end{array}$} & \multirow{3}{*}{$\begin{array}{c}\text { Lead plant in } \\
\text { Ridder }\end{array}$} & $\mathrm{Zn}$ & 23 & 20.6 & \multirow{3}{*}{$\mathrm{Pb}, \mathrm{Cu}, \mathrm{Zn}$} \\
\hline & & $\mathrm{Pb}$ & 6 & 645.7 & \\
\hline & & $\mathrm{Cu}$ & 3 & 151.9 & \\
\hline \multirow{3}{*}{$\begin{array}{l}\text { Near old } \\
\text { waste } \\
\text { storage }\end{array}$} & \multirow{3}{*}{$\begin{array}{c}\text { Tailing storage } \\
\text { of Zyryanovsk } \\
\text { mining plant }\end{array}$} & $\mathrm{Zn}$ & 23 & 230.2 & \multirow{3}{*}{$\mathrm{Zn}, \mathrm{Pb}, \mathrm{Cu}$} \\
\hline & & $\mathrm{Pb}$ & 6 & 221.2 & \\
\hline & & $\mathrm{Cu}$ & 3 & 129.6 & \\
\hline \multirow{3}{*}{$\begin{array}{l}\text { Hydro } \\
\text { dump }\end{array}$} & \multirow{3}{*}{$\begin{array}{l}\text { Zyryanovsk } \\
\text { mining plant }\end{array}$} & $\mathrm{Zn}$ & 23 & 73.7 & \multirow{3}{*}{$\mathrm{Zn}, \mathrm{Cu}, \mathrm{Pb}$} \\
\hline & & $\mathrm{Pb}$ & 6 & 9.6 & \\
\hline & & $\mathrm{Cu}$ & 3 & 24.5 & \\
\hline
\end{tabular}

The total soil contamination by heavy metals in the lead and zinc plants and waste storage in Ridder town is $Z c=88.71$, and that in the Zyryanovsk mining plant and waste storage is $Z c=108$.

\subsection{Contamination to vegetation}

The chemical composition of vegetation reflects the elemental composition of soils. Therefore, excessive accumulation of heavy metals in vegetation is conditioned, first of all, by their high concentrations in soils. Usually, the first barrier is roots, and then stems and leaves (Alekseev, 1987). Vegetations growing in the soil with dumps accumulate high concentrations of heavy metals in their organs. Accumulation of heavy metals in the organs of herbaceous species can be placed in the following order: $\mathrm{Zn}>\mathrm{Cu}>\mathrm{Pb}$ for mowing; $\mathrm{Zn}>\mathrm{Pb}>\mathrm{Cu}$ for falling; $\mathrm{Zn}>\mathrm{Cu}>\mathrm{Pb}$ for roots. Trees and shrubs growing in the soil with dump rocks also accumulate high concentrations of heavy metals in leaves and roots. Species growing in the same environmental conditions (with dumps) may be selective in their absorption of various elements. Accumulation of zinc in the organs of Caragana is in the order: seeds $>$ branches $>$ roots $>$ leaves $>$ husk. The total index of pollution for Caragana growing in the dumps with heavy metal is $Z c=9.83$, i.e. they are contained in the maximum allowable concentrations. Poplar is different from other species and has high absorption and storage of heavy metals in leaves and roots. It can be recommended for improving the 
sanitary conditions of mining areas.

\subsection{Contamination to invertebrates}

It is known that soil is inhabited by various groups of animals that are indicators of human disturbance on natural bio-systems. Soil invertebrates are indicators of soil pollution. In the study, we found 32 components of micro- and mesofauna, 23 of which were microarthropods and 9 of which were representatives of mesofauna.

Microarthropods were represented by different groups of mites (shell-Oribatei, TrombidiformesTrombidiformes), as well as Collembolas and Collembola. Of the shell mites, the representatives of 12 genera belonging to 9 families were found, and only one genus, i.e. Acarus of the family Acaridae, was Trombidiformes (Figs. 6a, b). Mites in the soil were mainly distributed in the upper soil layers of $0-5$ $\mathrm{cm}, 10-15 \mathrm{~cm}(80 \%-90 \%)$.

Collembola were represented by 10 genera belonging

(a)

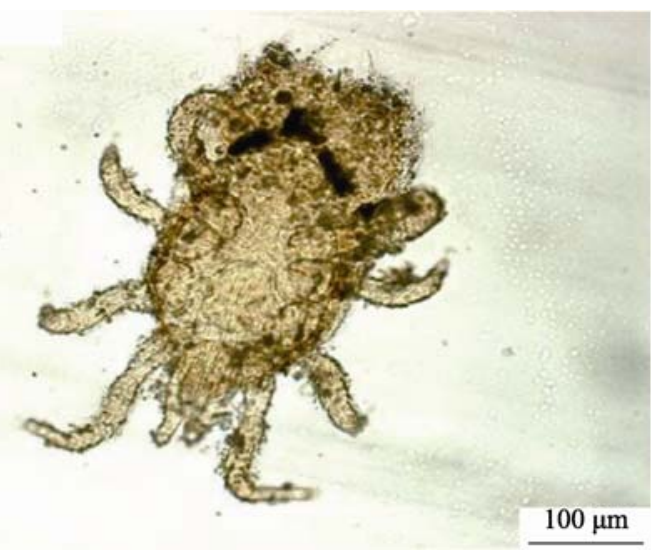

(b)

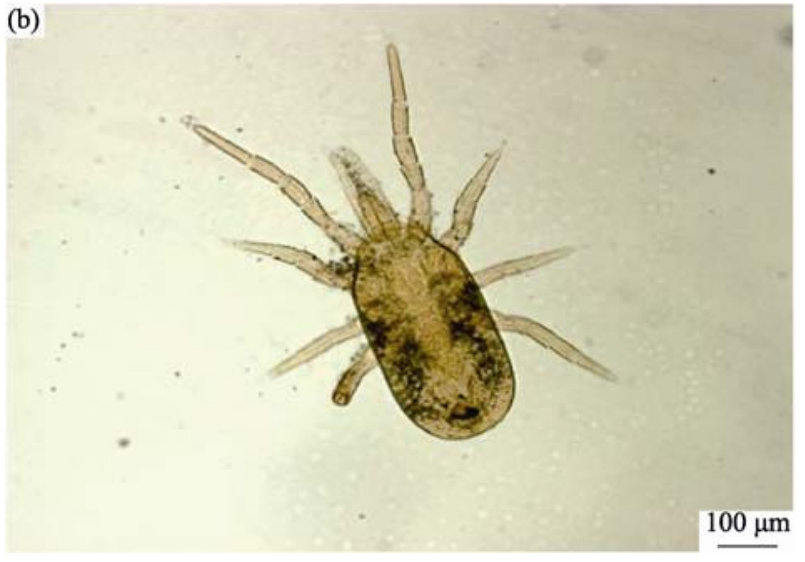

Fig. 6 Oribatei found in the $0-5 \mathrm{~cm}$ soil layer of site 12 to 7 families. Among the representatives of mesofauna earthworms (class Oligochaeta), centipedes (class Myriopoda), adult and larva of insects (class Jnsecta) and spiders (class Arachnida) were found.

Collembola were the representatives of 10 genera. Compared with the number of shell mites, the population of Collembola (Collembola) was $27.6 \%$ of the total number of studied microarthropods (Figs. 7a, b).

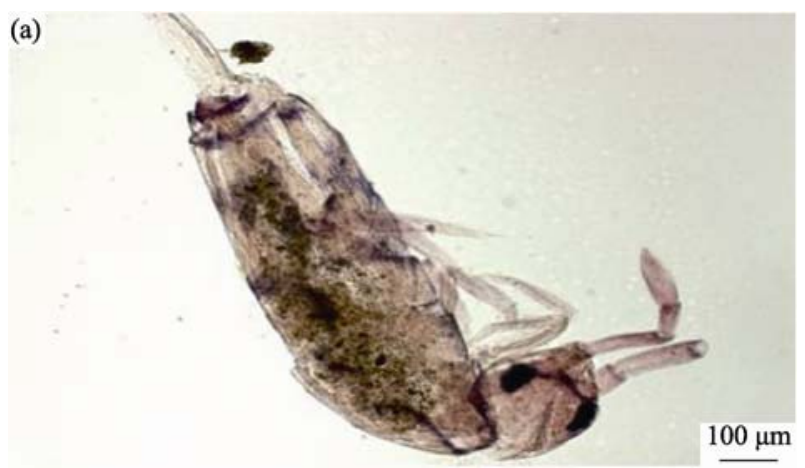

(b)

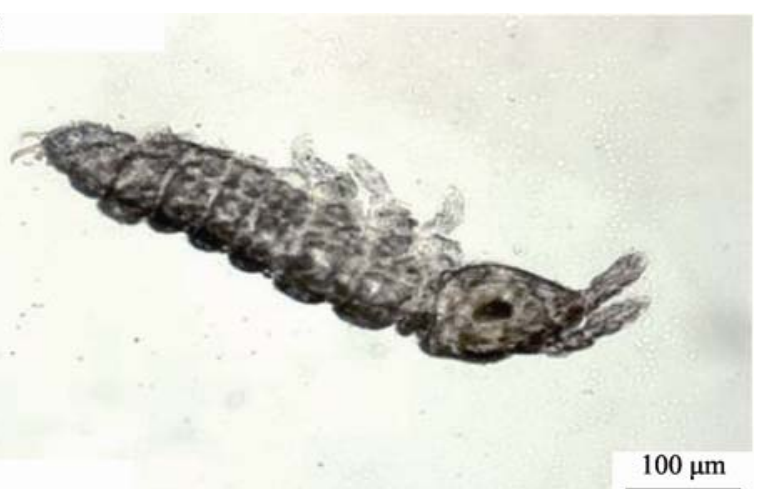

Fig. 7 Collembola found in the $10-15 \mathrm{~cm}$ soil layer of site 11

Like shell ticks, Collembola also occurred mainly in the upper soil layers of $0-5 \mathrm{~cm}, 5-10 \mathrm{~cm}$. This is probably due to the existence of a thin surface soil layer, the presence of vegetation, as well as the water absorbency of the soil.

The number of animals in mesofauna in the studied area ranged from 16 to 48 specimen $/ \mathrm{m}^{2}$. Millipedes (Myriopoda) were major components of soil mesofauna. They made up $38.4 \%$ (688 specimen $\left./ \mathrm{m}^{2}\right)$ of the total number of representatives of the mesofauna. Others were ants (Formica, 352 specimen $/ \mathrm{m}^{2}, 19.6 \%$ ) and larvae of Diptera (Diptera, 192 specimen $/ \mathrm{m}^{2}$, $10.7 \%$ ). 
A few earthworms (family Lumbricidae) were found at sites 10, 12 and 13. The small number of earthworms and other invertebrates assumes that soils of these areas have not yet acquired features peculiar to the soils rich in organic matter and moisture.

To summarize the qualitative and quantitative composition of invertebrates in the soils of remediate sites at Zyryanovsk lead plant, it should be noted that the main inhabitants of these areas are shell ticks of microfauna (Oribatei) and millipedes (Myriopoda) from mesofauna.

The small number of other groups of animals and their uneven distribution in the sites depend on the specific features of substrates, holding capacity of the soil layers and conditions of the habitat. The results of our study indicated that in contaminated soils the representatives of the mesofauna and microarthropods did not occur.

\subsection{Contamination to water}

Historically, due to technological necessity, all mining and metallurgy production facilities, as well as enterprises of thermal power are located on the banks of rivers. That's why the most significant problem in the basin of Ulba river is the industrial pollution by sewage and mine water. Ulba River is one of the largest right-bank tributaries of Irtysh River. Its origins are the rivers Breksa and Zhuravlikha, which merge together to make up Tikhaya River near Ridder mines, and in turn, converges with Gromotukha River to form the Ulba River. Rivers Breksa, Tikhaya and Ulba may be regarded as a single water stream, as they are a natural extension of each other. Due to this circumstance, it can be observed how the water quality of the rivers changes downstream. Analysis of water samples, taken near the waste storages and sewage water from Zyryanovsk deposit and Ridder town, revealed severe water contamination with heavy metals (Tables 4, 5).

Table 4 Concentration of heavy metals in the water samples taken in various places of Zyryanovsk

\begin{tabular}{cccccc}
\hline \multicolumn{7}{c}{$\mathrm{Mn}$} & $\mathrm{Cu}$ & $\mathrm{Zn}$ & $\mathrm{Cd}$ & $\mathrm{Pb}$ \\
\hline \multicolumn{5}{c}{$\mathrm{mg} / \mathrm{L}$} \\
\hline ZK-1 & $15.0 \pm 1.2$ & $4.4 \pm 0.3$ & $13.0 \pm 1.0$ & $0.36 \pm 0.03$ & $0.75 \pm 0.06$ \\
ZK-2 & $156.5 \pm 12.5$ & $19.2 \pm 1.5$ & $235.0 \pm 19.0$ & $3.10 \pm 0.25$ & $3.3 \pm 0.2$ \\
ZK-3 & $137 \pm 11.0$ & $19.0 \pm 1.5$ & $204 \pm 16.0$ & - & $0.75 \pm 0.06$ \\
ZK-4 & $55 \pm 5.0$ & $10 \pm 1.0$ & $1,544 \pm 139.0$ & $19.3 \pm 1.7$ & $26.8 \pm 2.4$ \\
ZK-5 & $133 \pm 11.0$ & $19.5 \pm 1.5$ & $171 \pm 14.0$ & $3.8 \pm 0.3$ & $4.5 \pm 0.3$ \\
ZK-5.1 & $128 \pm 12.0$ & $18.7 \pm 1.5$ & $169 \pm 15.0$ & $3.6 \pm 0.3$ & $3.7 \pm 0.3$ \\
ZK-6 & $93 \pm 7.0$ & $14.6 \pm 1.5$ & - & - & $1.3 \pm 0.1$ \\
ZK-7 & $625 \pm 50.0$ & $107 \pm 8.0$ & $1,121 \pm 90.0$ & $107 \pm 8.0$ & $54.6 \pm 4.5$ \\
ZK-8 & $13.4 \pm 1.0$ & $2.5 \pm 0.2$ & & $1.1 \pm 0.1$ & $1.3 \pm 0.1$ \\
MPC & 500.0 & $1,000.0$ & $1,000.0$ & 1.0 & 30.0 \\
Clarke & 10.0 & 7.0 & 2.0 & 0.01 & 1.0 \\
value & & & & & \\
\hline
\end{tabular}

Table 5 Analysis of river water samples in Ridder town (2010)

\begin{tabular}{|c|c|c|c|c|c|c|c|}
\hline \multirow{2}{*}{ Site of sampling } & \multicolumn{7}{|c|}{ Concentration in water $(\mathrm{mg} / \mathrm{L})$} \\
\hline & $\mathrm{Pb}$ & $\mathrm{Zn}$ & $\mathrm{Cu}$ & $\mathrm{Cd}$ & $\mathrm{Hg}$ & $\mathrm{Se}$ & $\mathrm{F}$ \\
\hline R. Zhuravlinka & 0.005 & 0.20 & $<0.005$ & $<0.0005$ & 0.0001 & 0.0002 & $<0.2$ \\
\hline R. Zhuravlinka & 0.005 & 0.29 & 0.005 & 0.001 & 0.0002 & 0.0002 & $<0.2$ \\
\hline R. Bystrukha & 0.020 & 0.38 & 0.025 & 0.0025 & $<0.00005$ & 0.0017 & $<0.2$ \\
\hline R. Bystrukha & 0.005 & 0.15 & 0.005 & 0.001 & 0.00005 & 0.0008 & 0.2 \\
\hline R. Philipovka & 0.015 & 0.34 & 0.025 & 0.0035 & 0.0001 & 0.0011 & 0.2 \\
\hline R. Philipovka & 0.005 & 0.08 & $<0.005$ & 0.0005 & $<0.00005$ & 0.0002 & 0.2 \\
\hline R. Bystrukha & 0.005 & 0.12 & $<0.005$ & 0.001 & 0.00005 & 0.0002 & $<0.2$ \\
\hline
\end{tabular}

These sources of water are dangerous for living organisms. The average coefficient of water migration of copper is $0.014-0.58$, zinc $0.007-1.08$, lead 0.004-0.79, chromium 0.034-0.44. The higher the water migration coefficient is, the stronger the leaching of the element from the rock is and the more intense the water migration becomes.

\section{Conclusions}

In soil samples taken from the sections of the tailing storages of Ridder town, laid near the zinc and lead plants, the content of heavy metals increased. 
The obtained results implied the degree of anthropogenic impact on the industrial complexes of Zyryanovsk and Tishinsk fields. In the study, the prior heavy metals and their sources of income into the soil-plant-water system have been identified. The main contaminants are lead, zinc and copper. Sources of pollution of natural ecosystems in Ridder town are the lead plant $(\mathrm{Pb}, \mathrm{Zn})$, zinc plant $(\mathrm{Zn}, \mathrm{Pb}, \mathrm{Cu})$, and waste storage $(\mathrm{Pb}, \mathrm{Zn}, \mathrm{Cu})$. In the Zyryanovsk deposit, the heavy meatls are from Zyryanovsk mining-enrichment plant $(\mathrm{Zn}, \mathrm{Pb}, \mathrm{Cu})$ and waste storage of Zyryanovsk mining-enrichment plant.

Vegetations growing in the dumps accumulate heavy metals in their organs. Accumulation of heavy metals in the organs of herbaceous species can be placed in the following way: cutting; $\mathrm{Zn}>\mathrm{Cu}>\mathrm{Pb}$; falling; $\mathrm{Zn}>\mathrm{Pb}>\mathrm{Cu}$; roots; $\mathrm{Zn}>\mathrm{Cu}>\mathrm{Pb}$. Poplar is different from other species in its high absorption and storage of heavy metals in leaves and roots. It can be recommended for the improvement of mining areas.

The qualitative and quantitative analyses of the composition of soil inhabitants in remediated sites of Zyryanovsk lead plant revealed that the main inhabitants of these areas are the shell ticks (Oribatei) of the microfauna and the mesofauna-millipedes (Myriopoda).

The small number of other groups of animals and their uneven distribution in the sites depend on the specifics of the substrates, the capacity of the soil layers and the conditions of their habitats. Our results indicate that there are no representatives of the mesofauna and microarthropods in contaminated soils and ground soils.

Analysis of water samples, collected near the tailing storages and sewage water in the Zyryanovsk deposit and Ridder town revealed severe contamination of the samples with heavy metals. These sources of water are dangerous for living organisms. The average coefficient of water migration of copper is 0.014-0.58, of zinc 0.007-1.08, of lead 0.004-0.79, and of chromium 0.034-0.44. The higher the water migration coefficient is, the stronger the leaching of the element from the rock is and the more intense the water migration becomes.

\section{Acknowledgments}

This work was supported by the International Science \& Technology Cooperation Program of China (2010DFA92720), the International Scientific-Technical Center Project (K-463), and the project 07N. (4.2.3) "Study of the ecosystem of disturbed lands and soil-forming processes on remediated phytotoxic dumps in EKR" and "Soil formation and evaluation of soilecological functions in techno-disturbed landscapes".

\section{References}

Alekseev Y V. 1987. Heavy Metals in Soils and Plants. Leningrad: Agropromizdat, 95.

Bulanov-Zakhvatkin E M. 1952. Collection and Study of Oribatid Mites. Moscow: Nauka, 29.

Deepak K B, Keshav S. 2012. Heavy metals accumulation from municipal solid wastes with different animal dung through vermicompsiting by earthworm Eisenia fetida. World Applied Science Journal, 17(1):133-139.

Gilyarov M S. 1975. Account of big invertebrates (Mesofauna). In: Methods of Soil-zoological Studies. Moscow: Nauka, 12-29.

Gilyarov M S, Striganova B R. 1987. Quantitative Methods in Soil Zoology. Moscow: Nauka.

Kasimov N S, Perelman A I. 1995. Geochemical Principles of Ecological and Geographical Taxonomy of Cities. Moscow: Ecogeochemistry of Urban Landscapes, 20-36.

Kloke A. 1980. Orientierungsdaten für tolerierbare gesamtgehalte einiger elemente in kulturboden mitt. VDLUFA. H. 1-3. 23-32.

Kovalsky V V. 1982. Geochemistry of the Environment and Life. Moscow: Nauka, 77.

Mambetkaziev E A, Lobanov F I, Mambetkazieva R A. 2001. The issue of preventing dusting of beaches of tail storages and ways of their solution. Journal Ecology of Eastern Kazakhstan, 27-31.

Min P, Hyo-Taek C, Laszlo M. 2010. Mobility and accumulation of selenium and its relationship with other heavy metals in the system rocks/soils-crops in areas covered by black shale in Korea. Journal of Geochemical Exploration, 107(2): 161-168.

Vinogradov A P. 1957. Geochemistry of Rare and Trace Elements in Soils. Moscow: Moscow Academy of Sciences, 238. 